\title{
The Implication of Child Labour on Educational Achievement: A Case Study in Assosa Town, Benishangul-Gumuz Regional State, Ethiopia
}

\author{
Terefe Admaw Bekure \\ Lecturer of Economics, College of Business and Economics, Assosa University, Assosa, Ethiopia
}

\begin{abstract}
This study aimed to identify the implications of child labour on child educational achievement. Cross sectional data randomly collected from 384 sample child labourers in Assosa town, were utilized in this study. Two- limits tobit estimator was employed for estimating the determinants of child educational achievement. The empirical result reveals that there is association between child labour and educational achivement. Thus, strengthening school based financial support and creating awareness are of paramount importance to fight child labour exploitation. Curbing the problem of child labour and improving academic achievement also requires reducing poverty.
\end{abstract}

Keywords: Child labour; Children's educational achievement; Two-limit tobit model

DOI: $10.7176 /$ RHSS/11-3-04

Publication date: February $28^{\text {th }} 2021$

\section{Introduction}

Thinking about the development of human resource without investing on education is a mere wish, especially for developing nations. To have more educated manpower, investment on children's education should become a worthwhile policy issue for countries whose human capital accumulation falls behind. Child labour exploitation in developing countries especially in sub-Saharan Africa and South Asian continues to be a controversial issue (Mahendra, 2013). Child labour in these countries affects school performance as children miss important lessons and fall behind academically (Ravinder, 2009).

Previous studies by (Udry, 2003; Priyambada et al., 2005; Sakuri, 2006) shows that Child labour is rooted in poverty and its relation to education is often considered two sides of the same coin. It is a result of current poverty and a cause of continued poverty for the children who sacrifice their education in order to work. It interferes with the human capital development of children by either forcing children to drop out of schools or making learning process in schools ineffective. Poverty and the need of poor families for income are the most important factors that push children to engage in working activities (Gebremedhin, 2013). According to Yibeltal et al., (2014) educational achievement is significantly affected by child work load.

According to the ILO (2013), 168 million children worldwide are engaged in child labour. Of these 168 million children, 85 million are engaged in what the ILO believes "hazardous work." The sub-Saharan African region has the second highest number of child labourers in the world with about 59 million engaged as child labour in 2012. Children aged 5 to 17 , or 21.4 percent, are involved in child labour while 10.4 percent are engaged in hazardous work. Only one out of five children involved in child labour is paid for his or her work. The majority of children in child labour perform unpaid family work.

Like other developing African countries, child labour is severe in Ethiopia. Children's below the working age are exploited for the sake of earning minimum wage for their long hour working. This indicates the severity of child labour in the country at cost of schooling (Beliyou, 2003). For example, Ethiopia was among 10 countries listed as worst forms of child labour in 2012. About 60 percent of children in Ethiopia are engaged in some forms of child labour. Many of these children work in the mining industry which poses the biggest dangers for child labourers. Many parents in developing countries push their children to work out of necessity. Unable to sustain their families on their own income, the parents feel that they have no choice but to push their children into child labour (Matt, 2014).

The severity of child labour on education is not studied in the area and in the current study; attention was given to econometric analysis to effectively account for other factors than child labour that could possibly affect students' academic achievements. Thus, the objective of this study is to identify the implications of child labour on child's educational achievement. Educational achievement was measured by semi-annual cumulative result (proxied by cumulative grade point average (CGPA)). More specifically, the study aims to

$>$ Investigate the extent of child labour in Assosa town.

$>$ Examine the effects of child labour on children's educational achievement.

\section{Research Methodology}

Assosa town is among the largest urban areas of Benshangul-Gumuz Regional State with a total population of 
61,265 and located in North West direction $667 \mathrm{Km}$ far from Addis Ababa. According to central statistics authority report Assosa town has four small administrative clusters- kebelles ${ }^{1}$ (CSA, 2016).

A cross-sectional study was utilized to examine the implication of child labour on educational achievement in Assosa town. The study utilized both primary and secondary sources. And the target population of the study was child labourers found in Assosa town. Children's aged 5-17 have been considered. Two stage sampling procedure was used to select kebelles and sample child labourers. In the first stage, three out of four kebelles were selected purposively on the basis of the degree of child labour participation (kebelles with higher child labour participation is considered) in the town. In the second stage 384 child labourers were selected using snow ball sampling method. In the data collection process, trained data collectors have been participated and conducted a face to face conversation with the sampled respondents. The collected data was analyzed by using both the qualitative and quantitative methods.

\section{Method of Data Analysis}

Both descriptive statistics and econometric techniques have been employed to describe, analyze and interpret the collected data. The econometric method is outlined here under.

\subsection{Econometric Model Specification}

Educational achievement was measured by test scores of children's in a semester. To analyze the effect of child labour on student's educational achievement using test score in a semester is preferable (Eduardo et al., (2009); Tassew and Aregawi, 2015)). Tobit model has been used for estimating the various factors of educational achievement.

The tobit model is a statistical model proposed by James Tobin (1958) to describe the relationship between a non-negative dependant variable yi and an independent variable or vector xi. The tobit model can be described in terms of a latent variable $\mathrm{y}^{*}$. Suppose, however that $\mathrm{yi}^{*}$ is observed if $\mathrm{yi}^{*}>0$ and is not observed if $\mathrm{yi}^{*} \leq 0$. Then the observed yi can be defined as

$$
\begin{gathered}
y i=\left\{\begin{array}{c}
y i *=\beta x i+u i \text { if } y i *>0 \\
0 \quad \text { if } y i * \leq 0
\end{array}\right. \\
U i \sim \operatorname{IIDN}\left(0, \sigma^{2}\right)
\end{gathered} .
$$

This is known as the tobit model and it is called censored regression model, because it is designed to estimate linear relationship between variables when there is either left or right censoring or both left and right censoring in the dependant variable (Maddala, 2005). Among the different types of tobit model, two-limit tobit model has been used to analyze the determinants of educational achievement which is measured by cumulative result/ average test score which have a minimum and maximum of 0 and 100 respectively. The model then specified as

$$
y i *=\beta x i+u i \quad \mathrm{i}=1,2,3
$$

$y_{i} *$ is the latent variable and $x i$ and $u i$ are the set of the explanatory variable and error terms respectively. If we denote $y_{i}$ the observed dependent variable,

$$
\begin{aligned}
& \qquad y_{i}=L_{1 i} \text { if } y_{i} \leq L_{1 i} \\
& =y_{i} * \text { if } L_{1 i}<y_{i} *<L_{2 i} \ldots \ldots \ldots \ldots \ldots \ldots \text { (3) } \\
& =L_{2 i} \text { if } y_{i} * \leq L_{2 i}
\end{aligned}
$$

Here $L_{1 i}$ and $L_{2 i}$, are the lower and upper limits respectively.

Where $y_{i}=$ the observed cumulative result of students

$y_{i} *=$ the latent variable which is not observed

$\beta=$ vector of unknown parameters

$x i=$ vector of independent variable affecting cumulative result

Cumulative result $(\mathrm{cmr})=f(\mathrm{sex}$, age, hhs, faedu, maedu, $t w h$, msh, minc, esh,$\mu i)$

\footnotetext{
${ }^{1}$ Kebelle is a smallest unit in Ethiopian administration system.
} 
Table 1: Definition of variables used in the analysis

\begin{tabular}{|c|c|}
\hline $\begin{array}{l}\text { Variables used } \\
\text { in the analysis }\end{array}$ & Variable definitions and Measurements \\
\hline TWH & Total working hours of child labourers per week \\
\hline CMR & Cumulative results of child labourers per semester (average) \\
\hline HHS & Household size \\
\hline AGE & Age of the child \\
\hline MINC & Monthly income of the child's parent \\
\hline SEX & 1 if the child is male; 0 otherwise \\
\hline MAEDU & $\begin{array}{l}\text { a categorical dummy for the level of education attained by child mother's ( } 1 \text { if illiterate; } 2 \text { if } \\
\text { primary school completed; } 3 \text { if secondary school completed; } 4 \text { if above secondary school }\end{array}$ \\
\hline FAEDU & $\begin{array}{l}\text { a categorical dummy for the level of education attained by child father's ( } 1 \text { if illiterate; } 2 \text { if } \\
\text { primary school completed; } 3 \text { if secondary school completed; } 4 \text { if above secondary school }\end{array}$ \\
\hline MSHH & $\begin{array}{l}\text { a categorical dummy for marital status of the household head ( } 1 \text { if single; } 2 \text { if married; } 3 \text { if } \\
\text { divorced; } 4 \text { if widowed) }\end{array}$ \\
\hline ESHH & 1 if the household head is employed; 0 otherwise \\
\hline
\end{tabular}

\section{Results and Discussion}

4.1. Demographic Characteristics of the Sample Respondents

Table 2: Age group and sex of the respondents

\begin{tabular}{|l|l|l|l|l|}
\hline \multirow{2}{*}{ Age group } & Sex & Respondents \\
\cline { 2 - 5 } & Male & Female & Total number & Percentage \\
\hline $5-8$ & 10 & 5 & 15 & 3.91 \\
\hline $9-13$ & 88 & 70 & 158 & 41.15 \\
\hline $14-17$ & 131 & 80 & 211 & 54.95 \\
\hline Total & 229 & 155 & 384 & $100 \%$ \\
\hline
\end{tabular}

Source: Own survey (2019)

The survey reveals that, from those students who combine schooling with work, $155(40.36 \%)$ are females and $229(59.64 \%)$ are males. It implies that male respondents' are higher in number than female. The mean age of child with in child labour is 13 . In addition, age of child has positive relationship with child labour, because the data shows as $54.95 \%$ of child labour are within the age range of $14-17$, whereas $41.15 \%$ are in the range of 9-13. Child labour increase with increase in age of the child.

Table 3: Children's working hours per week

\begin{tabular}{|l|l|l|}
\hline Hours per week & Frequency & Percentage \\
\hline $5-20$ & 49 & 12.76 \\
\hline $21-35$ & 138 & 35.94 \\
\hline $36-50$ & 117 & 30.47 \\
\hline $51-65$ & 64 & 16.67 \\
\hline $66-75$ & 16 & 4.17 \\
\hline Total & 384 & 100 \\
\hline
\end{tabular}

Source: Own survey (2019)

As it is clearly shown from the above frequency distribution table, 138 (35.94\%) \% of the respondents are working for 21-35 hours per week followed by 36-50 hours per week accounting $117(30.47 \%)$ of the total respondents'. About $64(16.67 \%)$ of them are working 51-65 hours per week followed by $49(12.76 \%), 16(4.17 \%)$ with working hours of 5-20 and 66-75 respectively. This hour is even almost double of ILO maximum restriction of child labour hour for children's under the age of 18 i.e. 43 hours per week. The mean working hour of the child per week is 37.53646 with minimum of 5 and maximum of 72 hour.

Table 4: Displays children's average score

\begin{tabular}{|l|l|l|}
\hline Average score & Frequency & Percentage \\
\hline$<50$ & 184 & 47.92 \\
\hline $50-59$ & 59 & 15.36 \\
\hline $60-79$ & 92 & 23.96 \\
\hline $80-89$ & 31 & 8.07 \\
\hline $90-100$ & 18 & 4.69 \\
\hline Total & 384 & 100 \\
\hline
\end{tabular}

Source: own survey (2019)

The table shows that respondents semester average cumulative result. Most of the respondents' 184(47.92\%) of them reported that their semester average score is below half (50) and the reason for these low score is 
participation of in labour activities. About 92(23.96\%), 59(15.36\%), 31(8.07\%) and 18(4.69\%) of the children reported their semester average score as satisfactory, fair, very good and excellent respectively. The mean of their semester score is 56.43 while the minimum and maximum test scores are 30 and 99 respectively. This information tells us most of child labourers score below the required level and though some children's score good result together with work, this does not represent the score of most of the students. The reality is children's participation in different types of work affects their schooling seriously as compared to those students who are not working.

\subsection{Econometric Analysis}

\subsubsection{Determinats of Child's Educational Achievement: Two Limit Tobit Estimator Result}

In this case, cumulative result per semester (average test score) is the dependent variable. Two-limit Tobit model has been used for estimating the model. To cope up with the limitation of tobit model in detecting the problem of hetroskedasticity, the analysis is done using interval regression (Jemal, 2011). Prior to running the regression, the model is checked for the existence of data problems mainly multicollinerity and omitted variable bias. After doing this procedure, final output of interval regression is presented as follows.

Table 5: Regression result for educational achievement

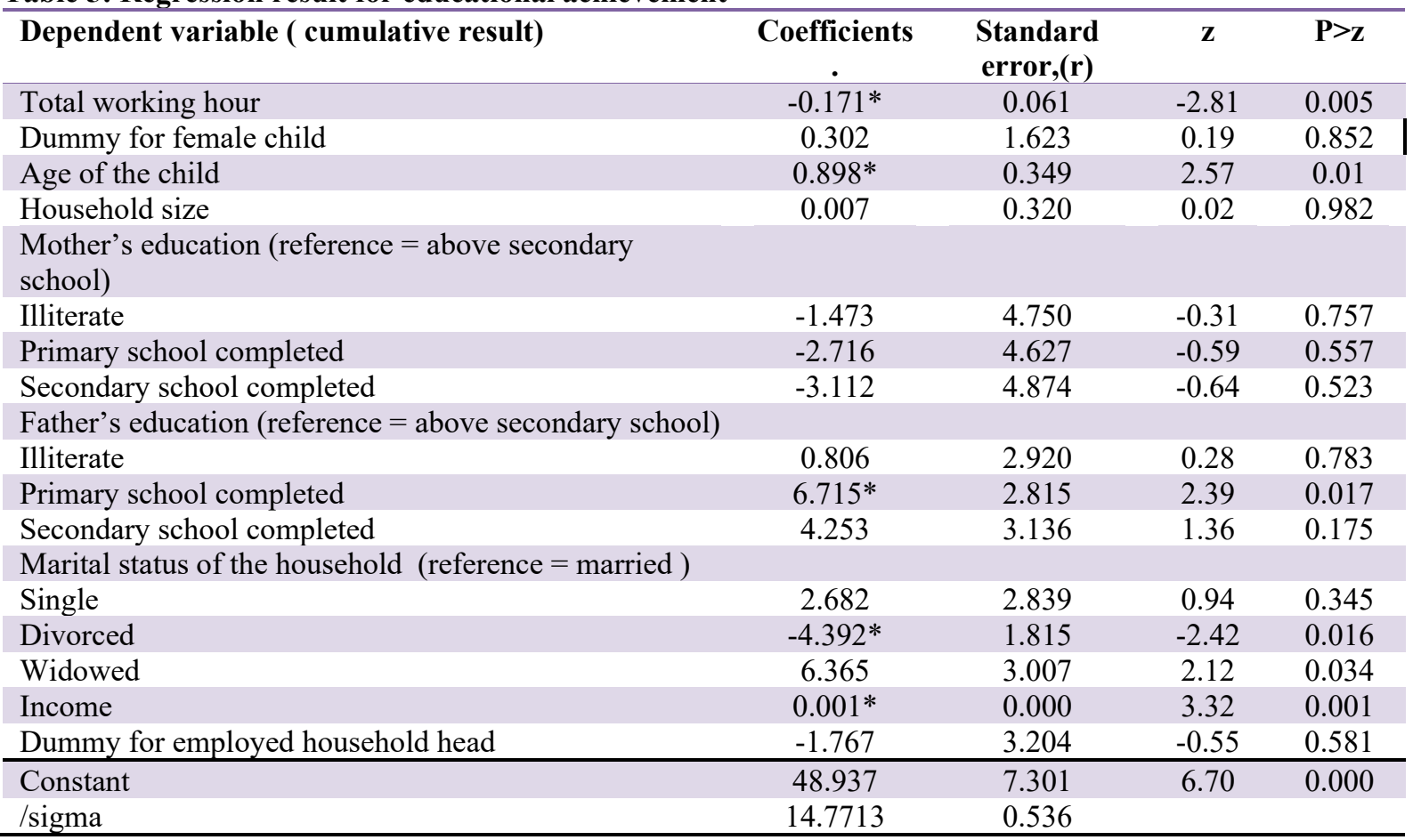

Source: Author's estimations (2019)

Note: Standard errors are robust; *significant at 1\%; Observation summary: 3 left-censored observations; 381 uncensored observations; Number of obs $=384$; Wald chi2 $(15)=104.24$; Log pseudolikelihood $=-1570.3447$; Prob $>$ chi $2=0.0000$.

As can be seen in Table 5, child labour hour per (TWH) week is negatively associated with cumulative result and significant at $1 \%$. That is, as weekly child labour time increases by an hour, the child's cumulative result falls by 0.17 points. There is a negative and significant effect of child labour on educational achievement of children's (Yibeltal et al., 2014). Age of the child (AGE) shows the positive relationship between age of children and cumulative result. When the age of the child is increases there is a way to improve or to increase his/her test score and it is significant at $1 \%$.

Monthly income of child's parent (MINC) is also significant at 1\% level of significance. Parent's income level positively affects cumulative result and off course it is natural to expect when the income level of parents increases children's participation in school is higher than their participation in work so that improvement in the academic achievement will take the way and for parents whose income is low the opposite is true. Higher family income associated with higher demand for education. Parental income has a positive and significant effect on children's test scores (Eduardo et al., 2009).

Coming to the educational level of child's parents with in the household, educational level of the child's father (FAEDU) found to be statistically significant at $1 \%$, but mothers' education is not statistically significant. Fathers' education was highly significant and has a positive impact on children's academic achievement. Household head whose marital status (MSHH) is divorced is significant at $1 \%$ and it affects cumulative result of children's negatively. 


\section{Conclusion and Recommendations}

This study investigates whether child labour affects the educational achievement. Cross sectional data collected from child labourers in Assosa town, revealed a negative effect of child labour on child's educational achievement. The empirical results of this study shows that educational achievement is positively associated with age of the child, monthly income of child's parent, educational level of child's father. However, marital status of the household head (divorced) and total working hours of the child per week are negatively associated with the child's educational achievement.

The indication is that child labour hour has a negative impact on child's educational achievement in Assosa town. Projects should be undertaken to improve parental education and to combat child labour. This is because, parents' schooling, especially fathers' schooling continues to have a strong positive impact on children's school achievement. Accordingly, the study suggests that the government should provide subsidies and credit facility for the poor, and strengthen poverty reduction program to achieve its goal of achieving quality education for all.

\section{References}

Beliyou, A. (2003). Child Domestic Work in Ethiopia: An Empirical Investigation. MSc. Addis Ababa Ethiopia. CSA. (2016). CSA office, Assosa branch: Statistical information on the population of Assosa. Assosa.

Eduardo G, Analucia, K and Arends, K. (2009). The impact of child labour and school quality on academic achievement in brazil, Discussion paper, No. 4062.

Gebremedhin, H. (2013). Determinants of child labour and its effects on the Children's schooling, the case of Mekelle city, Tigray, Ethiopia.

ILO. (2013). Facts on Child Labour,Geneva.

James, T.(1958). Estimations of Relationships for Limited Dependent Variables. Econometrica, Vol.26, No.1.(Jan., 1958), PP.24-36

Jemal, A. (2011). Microfinance and Loan Repayment Performance:The case study of the oromia credit and saving share company(OCSSCO) in Kuyu.

Mahendra, R. (2013). Child Labour Use in a Small Developing Country: Is it Luxury, Distributional or Substitution Axiom? . International Journal of Business and Social Research (IJBSR), Volume -3 .

Matt, B. (2014, October). Borgen project. Retrieved from (http://borgenproject.org/10-child-labour-facts/)

Priyambada, A, Suryahadi, A and Sumarto,S. (2003). What Happened to Child Labour in Indonesia during the Economic Crisis: The Trade-off between School and Work, SMERU Research Institute, Jakarta.

Ravinder, R. (2009). The Child Labour in Developing Countries; A Challenge to Millennium Development Goals. Sakurai, R. (2006). Child Labour and Education, Background paper prepared for the Education for All Global Monitoring Report 2007 Strong foundations, Early childhood care and education, UNESCO.

Tassew, W and Aregawi, G. (2015). Is Child Work Determintal to the Educational Achivement of Childrens? Results from young lives in Ethiopia.

Udry, C. (2003). Child labour (Centre Discussion Paper No. 856); Economic Growth centre, Yale University.

Yibeltal A, Tewodros G and Hailemariam A. (2014). Analysis of the Determinants of Academic Achievement of Primary Education: A Case Study on Grade Eight Students at Lay Gayint Wereda in Amhara Regional State. Science Journal of Education.Vol.2 , 131-136. 